\title{
INVESTIGATING THE EFFECTS OF DEMOGRAPHIC VARIABLES ON THE ROLE OF MEDIA EDUCATIONS OF IRAN HELAL INSTITUTE IN INCREASING PUBLIC AWARENESS FOR REHABILITATION AFTER EARTHQUAKE IN THE POSSIBLE EARTHQUAKE IN TEHRAN
}

\author{
Zahra Filom \\ Department of Social Communication Sciences, Islamic Azad University, Iran \\ anita.filom@yahoo.com
}

\begin{abstract}
The aim of this study was to investigating the effects of demographic variables on the role of media educations of Iran Helal institute in increasing public awareness for rehabilitation after earthquake in the possible earthquake in Tehran. In the quantitative research, using survey method and questionnaire tool, investigating the role of educational media of Helal institute on public awareness for rehabilitation after earthquake. The study population included all persons 15-65 years at the time of implementation of project were living in 5 regions in North, South, East, West and center of Tehran. Sample size $n=380$ in each region is calculated based on Cochran formula. Overall, this study shows that media educations of Helal institute on people's awareness about prevention and preparing and informing the public about the rehabilitation after the earthquake is effective.
\end{abstract}

Keywords: media educations, Iran Helal Institute, public awareness, possible earthquake in Tehran

\section{TAHRAN'DA OLASI DEPREM SONRASI REHABILITASYON TOPLUM BILLINCININ ARTIRILMASI İRAN HELAL ENSTITÜSÜ MEDYA EĞITIMIN ROLÜ KONULU DEMOGRAFIK DEĞISSKENLER ETKILERININ ARAŞTIRILMASI}

ÖZ

Bu çalışmanın amacı, Tahran'da olası bir depremde depremden sonra rehabilitasyon için kamu bilincinin artırılması İran Helal enstitüsü medya eğitimleri rolüne ilişkin demografik değişkenlerin etkilerini araştıran oldu. Nicel araştırmada, depremden sonra rehabilitasyon için halkın bilinçlendirilmesi üzerinde Helal enstitüsü eğitim medyanın rolünü araştıran, anket yöntemi ve anket aracını kullanarak. Araştırmanın evrenini, projenin uygulanması sırasında 15-65 yıl Kuzey, Güney, Doğu, Batı ve Tahran merkezinde 5 bölgede yaşayan tüm kişileri dahil. Her bölgedeki Örnek büyüklüğü $n=380$ Cochran formülü esas alınarak hesaplanır. Genel olarak, bu çalışma önlenmesi ve hazırlanması ve deprem sonrası rehabilitasyonu hakkında kamuoyunu bilgilendirme konusunda insanların farkındalık Helal enstitüsü medya eğitimler etkili olduğunu göstermektedir.

Anahtar Kelimeler: Medya ĕgitimler, Iran Helal Enstitüsü, halkın bilinçlendirilmesi, Tahran'da olası deprem

\section{INTRODUCTION}

Natural and non-natural disasters and accidents are threatening human life and yet one of the pillars of human evolution and every year taken thousands of victims around the world and will cause large financial damages. In fact, human losses and natural disasters and accidents in the world, a figure more 
than ten thousand a month is estimated and our country due to its geographical location, has repeatedly faced with the occurrence of disasters and accidents and according to evidence and statistics, Iran is among the top ten disaster-prone countries in the world. Despite considerable progress there is not enough growth in technologies post-traumatic response in the prevention and preparedness and failed to prevent or reduce the risks of it seriously. (1) Based on studies in Tehran, faults, including fault in northern and southern areas of Tehran such as Darabad, Niavaran, Narmak, Tajrish, Ghasr Firoozeh in active condition and if the fault resistance ceases occurred in the event of earthquake in Tehran more than 5 million people will lose their lives.

According to study of JICA Japan's International Cooperation Department (JICA) the possibility of activating these three fault, south Ray and north Tehran was diagnosed that activate any damage and various intensity in each region of Tehran.

In Tehran historical records, large earthquakes such as earthquake 7.1 magnitude Damavand in 1830, earthquake 7.2 magnitude in 1117 AD in Karaj, 7.7magnitude Taleghan in 958 AD, earthquake 7.1 magnitude in $855 \mathrm{AD}$ in Ray and many more earthquakes above 7 was registered in Tehran. Tehran earthquake return period about 150 to 200 years, since the last strong earthquake over the past 170 years is a very high risk of earthquake in Tehran. The present study aims to investigate the effects of demographic variables on the role of educational media of Iran Helal Institute in increasing public awareness for rehabilitation after possible earthquake in Tehran is measured. (2)

\section{THEORETICAL FOUNDATIONS AND RESEARCH LITERATURE THEORIES OF SOCIAL COMMUNICATION}

In the field of "social communication", several theories have been proposed, there are some of which in other fields of "Human Science" as "sociology" and "behavioral science" as well. Theories such as "Hypodermic Theory", strength theory, the theory of "Usage and Satisfaction", the theory of "AgendaSetting", the theory of " audience dependency " and "Public Relation Expert", aware of these theories and know their application in public relations. (3)

\section{DIFFUSION THEORY}

"Diffusion theory", is another theory for analyzing the people, how to accept or reject information. According to this theory, the "Diffusion", a process through which the "Innovation" of specified channels during the given period, among members of a social system is published. (4) The most complete theory of diffusion, "Everet Rogers", an American professor of communications science, in the book "diffusion of innovation" is raised. Rogers, believes that people, information resulted of innovations adopt through the five stages that each of these steps has their specific features. The steps are as follows: awareness, motivation and persuasion, decision and evaluation, implementation and acceptance and consolidation phase. (5)

\section{RESEARCH LITERATURE}

A research by Malek Mohammadi, Mohammad (2006) entitled "public education, self-aid education, the role of mass media, training courses and exercises in Shahr Kord city Red Crescent" as quasiexperimental research carried. And the results suggest the need to go through training courses, educational books, radio and television, watch instructional videos, holding maneuvers to train how to deal flood, fire, etc., as well as teaching aid and first aid as a preventive measure in the face of natural disasters. (6)

A study by Mehdi Pour, Abtin (2003) entitled "Strategies for the development of self-aid in the country with public education and public participation 'has been done to investigate the role of public participation in disaster. Research findings show education through TV and media are the best practices on ways to improve the efficiency index in human societies and for a comprehensive and grassroots participation in disaster for all age and social groups training should be provided. (7)

Research by Ghanjal, Ali (2003) examines "the role of self-aid in unexpected events" is done. These results confirmed the importance of proper training of population to initial relief to quickly and accurately that this will cause significant that the lives saved from death and that the damage can be prevented further trauma patients. (8) 
Research by Lorna (2003) did tick prevention education. The results emphasize the impact of education through the use of audio, visual and formed workgroups and evaluation methods. (9)

\section{RESEARCH HYPOTHESIS}

3.1 There is significant relationship between age and the effectiveness of media educations of Iran Helal institute in increasing public awareness for rehabilitation after possible earthquake in Tehran

3.2 There is significant relationship between gender and the effectiveness of media educations of Iran Helal institute in increasing public awareness for rehabilitation after possible earthquake in Tehran

3.3 There is significant relationship between the location and the effectiveness of media educations of Iran Helal institute in increasing public awareness for rehabilitation after possible earthquake in Tehran 3.4 There is significant relationship between education and the effectiveness of media educations of Iran Helal institute in increasing public awareness for rehabilitation after possible earthquake in Tehran

3.5 There is significant relationship between employment status and the effectiveness of media educations of Iran Helal institute in increasing public awareness for rehabilitation after possible earthquake in Tehran

\section{RESEARCH METHODOLOGY}

The study is quantitative research; using survey method and questionnaire tool, the role of media educations of Helal institute in increasing public awareness were discussed. The study population included all persons $15-65$ years in Tehran and sample size $n=380$ in each region are calculated based on Cochran formula.

\section{RESULTS}

\section{THE FIRST HYPOTHESIS ANALYSIS}

H0: There is not significant relationship between age and the effectiveness of media educations of Iran Helal institute in increasing public awareness for rehabilitation after possible earthquake in Tehran H1: There is significant relationship between age and the effectiveness of media educations of Iran Helal institute in increasing public awareness for rehabilitation after possible earthquake in Tehran

Table 1 Investigating relationship between age and the effects of media education Iran Helal Institute at increasing public awareness about possible earthquake rehabilitation after the earthquake in Tehran

\begin{tabular}{|c|c|c|c|c|c|c|c|c|}
\hline $\begin{array}{l}\text { Age } \\
\text { Awarene }\end{array}$ & & & $\begin{array}{l}15 \text { to } 25 \\
\text { years }\end{array}$ & $\begin{array}{l}26 \text { to } 35 \\
\text { years }\end{array}$ & $\begin{array}{l}36 \text { to } 45 \\
\text { years }\end{array}$ & $\begin{array}{l}46 \text { to } \\
55\end{array}$ & $\begin{array}{l}56 \text { and } \\
\text { above }\end{array}$ & Total \\
\hline $\begin{array}{l}\text { Previous } \\
\text { score }\end{array}$ & $\begin{array}{l}\text { Lower than } \\
\text { average }\end{array}$ & $\begin{array}{l}\text { Number } \\
\text { Percent }\end{array}$ & $\begin{array}{l}492 \\
62.27\end{array}$ & $\begin{array}{l}272 \\
68\end{array}$ & $\begin{array}{l}232 \\
66.28\end{array}$ & $\begin{array}{l}153 \\
76.5\end{array}$ & $\begin{array}{l}88 \\
55\end{array}$ & $\begin{array}{l}1237 \\
65.11\end{array}$ \\
\hline & $\begin{array}{l}\text { Above } \\
\text { average }\end{array}$ & $\begin{array}{l}\text { Number } \\
\text { Percent }\end{array}$ & $\begin{array}{l}298 \\
37.73\end{array}$ & $\begin{array}{l}128 \\
32\end{array}$ & $\begin{array}{l}118 \\
33.71\end{array}$ & $\begin{array}{l}47 \\
23.5\end{array}$ & $\begin{array}{l}72 \\
45\end{array}$ & $\begin{array}{l}663 \\
34.89\end{array}$ \\
\hline Next Score & $\begin{array}{l}\text { Lower than } \\
\text { average }\end{array}$ & $\begin{array}{l}\text { Number } \\
\text { Percent }\end{array}$ & $\begin{array}{l}420 \\
53.16 \\
\end{array}$ & $\begin{array}{l}198 \\
49.5\end{array}$ & $\begin{array}{l}189 \\
54 \\
\end{array}$ & $\begin{array}{l}163 \\
81.5 \\
\end{array}$ & $\begin{array}{l}89 \\
55.63 \\
\end{array}$ & $\begin{array}{l}1059 \\
55.73 \\
\end{array}$ \\
\hline & $\begin{array}{l}\text { Above } \\
\text { average }\end{array}$ & $\begin{array}{l}\text { Number } \\
\text { Percent }\end{array}$ & $\begin{array}{l}370 \\
46.84\end{array}$ & $\begin{array}{l}202 \\
50.5\end{array}$ & $\begin{array}{l}161 \\
46\end{array}$ & $\begin{array}{l}37 \\
18.5\end{array}$ & $\begin{array}{l}71 \\
44.37\end{array}$ & $\begin{array}{l}841 \\
44.27\end{array}$ \\
\hline Total & & 790 & & 400 & 350 & 200 & 160 & 1900 \\
\hline
\end{tabular}

\begin{tabular}{|l|l|l|l|l|}
\hline Test & Value & Degrees of freedom & Significance level & Cramer coefficient \\
\hline Chi square & $\mathbf{9 . 5 4}$ & $\mathbf{4}$ & $\mathbf{0 . 1 2 3}$ & $\mathbf{0 . 1 1 2}$ \\
\hline
\end{tabular}

The results indicate that there is not significant relationship between age and the effectiveness of media educations of Iran Helal institute in increasing public awareness for rehabilitation after possible earthquake in Tehran. Therefore, $\mathrm{H} 0$ is accepted and $\mathrm{H} 1$ is rejected. 


\section{THE SECOND HYPOTHESIS ANALYSIS}

$\mathrm{H} 0$ : There is not significant relationship between gender and the effectiveness of media educations of Iran Helal institute in increasing public awareness for rehabilitation after possible earthquake in Tehran H1: There is significant relationship between gender and the effectiveness of media educations of Iran Helal institute in increasing public awareness for rehabilitation after possible earthquake in Tehran

Table 2 Investigating relationship between gender and the effectiveness of media educations of Iran Helal institute in increasing public awareness for rehabilitation after possible earthquake in Tehran

\begin{tabular}{|l|l|l|l|l|l|}
\hline \multicolumn{1}{|c|}{ Gender } & Awareness & & Woman & Men & Total \\
\hline Previous score & Lower than average & Number Percent & 810 & 398 & 1208 \\
& & & 57.98 & 79.13 & 63.57 \\
\cline { 2 - 6 } & Above average & Number & 587 & 105 & 692 \\
& & Percent & 42.02 & 20.87 & 36.43 \\
\hline Next Score & Lower than average & Number & 790 & 302 & 1092 \\
& & Percent & 56.54 & 60.04 & 57.47 \\
& & & & & \\
\cline { 3 - 6 } & Above average & Number & 607 & 201 & 808 \\
& & Percent & 43.46 & 39.96 & 42.53 \\
\hline Total & 1397 & & 503 & 1900 \\
\hline
\end{tabular}

\begin{tabular}{|l|l|l|l|l|}
\hline Test & Value & $\begin{array}{l}\text { Degrees of } \\
\text { freedom }\end{array}$ & $\begin{array}{l}\text { Significance } \\
\text { level }\end{array}$ & $\begin{array}{l}\text { Cramer } \\
\text { coefficient }\end{array}$ \\
\hline Chi square & 8.54 & 4 & 0.145 & 0.111 \\
\hline
\end{tabular}

The results indicate that there is not significant relationship between gender and the effectiveness of media educations of Iran Helal institute in increasing public awareness for rehabilitation after possible earthquake in Tehran

Therefore, $\mathrm{H} 0$ is accepted and $\mathrm{H} 1$ is rejected.

\section{THE THIRD HYPOTHESIS ANALYSIS}

$\mathrm{H} 0$ : There is not significant relationship between the location and the effectiveness of media educations of Iran Helal institute in increasing public awareness for rehabilitation after possible earthquake in Tehran H1: There is significant relationship between the location and the effectiveness of media educations of Iran Helal institute in increasing public awareness for rehabilitation after possible earthquake in Tehran

Table 3 Investigating relationship between the location and the effectiveness of media educations of Iran

Helal institute in increasing public awareness for rehabilitation after possible earthquake in Tehran

\begin{tabular}{|l|l|l|l|l|l|l|l|l|}
\hline Location & & North & East & Center & South & West & Total \\
\hline $\begin{array}{l}\text { Previous } \\
\text { score }\end{array}$ & $\begin{array}{l}\text { Lower than } \\
\text { average }\end{array}$ & $\begin{array}{l}\text { Number } \\
\text { Percent }\end{array}$ & $\begin{array}{l}222 \\
58.4\end{array}$ & $\begin{array}{l}219 \\
57.63\end{array}$ & $\begin{array}{l}216 \\
56.84\end{array}$ & $\begin{array}{l}220 \\
57.89\end{array}$ & $\begin{array}{l}225 \\
59.21\end{array}$ & $\begin{array}{l}1102 \\
58\end{array}$ \\
& & & & & & & & \\
\cline { 2 - 8 } & $\begin{array}{l}\text { Above } \\
\text { average }\end{array}$ & $\begin{array}{l}\text { Number } \\
\text { Percent }\end{array}$ & $\begin{array}{l}158 \\
41.57\end{array}$ & 42.36 & 43.15 & 42.10 & 40.78 & 42 \\
& & & & & & & & \\
\hline
\end{tabular}




\begin{tabular}{|l|l|l|l|l|l|l|l|l|}
\hline $\begin{array}{l}\text { Next } \\
\text { Score }\end{array}$ & $\begin{array}{l}\text { Lower than } \\
\text { average }\end{array}$ & $\begin{array}{l}\text { Number } \\
\text { Percent }\end{array}$ & $\begin{array}{l}189 \\
49.73\end{array}$ & $\begin{array}{l}186 \\
48.94\end{array}$ & 48.15 & 47.63 & 47.10 & 48.31 \\
& & & & & & & & \\
\cline { 2 - 9 } & $\begin{array}{l}\text { Above } \\
\text { average }\end{array}$ & $\begin{array}{l}\text { Number } \\
\text { Percent }\end{array}$ & 50.26 & 51.05 & 51.84 & 52.36 & 52.89 & 51.68 \\
& & & & & & & \\
\hline \multicolumn{1}{|l|}{ Total } & & & & & & & & \\
\hline
\end{tabular}

\begin{tabular}{|l|l|l|l|l|}
\hline Test & Value & $\begin{array}{l}\text { Degrees of } \\
\text { freedom }\end{array}$ & $\begin{array}{l}\text { Significance } \\
\text { level }\end{array}$ & $\begin{array}{l}\text { Cramer } \\
\text { coefficient }\end{array}$ \\
\hline Chi square & 10.16 & 4 & 0.136 & 0.135 \\
\hline
\end{tabular}

The results indicate that there is not significant relationship between the location and the effectiveness of media educations of Iran Helal institute in increasing public awareness for rehabilitation after possible earthquake in Tehran. Therefore, $\mathrm{H} 0$ is accepted and $\mathrm{H} 1$ is rejected.

\section{THE FOURTH HYPOTHESIS ANALYSIS}

$\mathrm{H} 0$ : There is not significant relationship between education and the effectiveness of media educations of Iran Helal institute in increasing public awareness for rehabilitation after possible earthquake in Tehran H1: There is significant relationship between education and the effectiveness of media educations of Iran Helal institute in increasing public awareness for rehabilitation after possible earthquake in Tehran

Table 4 Investigating relationship between education and the effectiveness of media educations of Iran Helal institute in increasing public awareness for rehabilitation after possible earthquake in Tehran

\begin{tabular}{|c|c|c|c|c|c|c|c|c|c|}
\hline \multicolumn{2}{|c|}{$\begin{array}{l}\text { Education } \\
\text { Awareness }\end{array}$} & \multicolumn{2}{|c|}{ High school } & \multirow{2}{*}{$\begin{array}{l}\text { Diploma } \\
485 \\
93.26 \\
\end{array}$} & \multicolumn{2}{|c|}{$\begin{array}{l}\text { Associate } \\
\text { Degree }\end{array}$} & \multicolumn{2}{|c|}{$\begin{array}{l}\text { Bachelor's } \\
\text { Degree } \\
\text { higher }\end{array}$} & \multirow{2}{*}{$\begin{array}{l}\text { Total } \\
\\
1508 \\
79.36 \\
\end{array}$} \\
\hline \multirow[t]{2}{*}{ Previous score } & $\begin{array}{l}\text { Lower than } \\
\text { average }\end{array}$ & $\begin{array}{l}\text { Number } \\
\text { Percent }\end{array}$ & $\begin{array}{l}532 \\
87.21\end{array}$ & & \multicolumn{2}{|c|}{$\begin{array}{l}123 \\
58.58\end{array}$} & \multicolumn{2}{|c|}{$\begin{array}{l}368 \\
65.71\end{array}$} & \\
\hline & $\begin{array}{l}\text { Above } \\
\text { average }\end{array}$ & $\begin{array}{l}\text { Number } \\
\text { Percent }\end{array}$ & $\begin{array}{l}78 \\
12.78\end{array}$ & $\begin{array}{l}35 \\
6.74\end{array}$ & \multicolumn{2}{|l|}{$\begin{array}{l}87 \\
41.42\end{array}$} & \multicolumn{2}{|l|}{$\begin{array}{l}192 \\
34.28\end{array}$} & $\begin{array}{l}392 \\
20.64\end{array}$ \\
\hline \multirow[t]{2}{*}{ Next Score } & $\begin{array}{l}\text { Lower than } \\
\text { average }\end{array}$ & $\begin{array}{l}\text { Number } \\
\text { Percent }\end{array}$ & $\begin{array}{l}456 \\
74.75\end{array}$ & $\begin{array}{l}412 \\
79.24\end{array}$ & \multicolumn{2}{|l|}{$\begin{array}{l}98 \\
46.66\end{array}$} & \multicolumn{2}{|l|}{$\begin{array}{l}312 \\
55.72\end{array}$} & $\begin{array}{l}1278 \\
67.26\end{array}$ \\
\hline & $\begin{array}{l}\text { Above } \\
\text { average }\end{array}$ & $\begin{array}{l}\text { Number } \\
\text { Percent }\end{array}$ & $\begin{array}{l}154 \\
25.24 \\
\end{array}$ & $\begin{array}{l}108 \\
20.76\end{array}$ & \multicolumn{2}{|l|}{$\begin{array}{l}112 \\
53.34\end{array}$} & \multicolumn{2}{|l|}{$\begin{array}{l}248 \\
44.28\end{array}$} & $\begin{array}{l}622 \\
3274 \\
\end{array}$ \\
\hline \multicolumn{2}{|l|}{ Total } & \multicolumn{2}{|l|}{610} & 520 & 210 & & 560 & & 1900 \\
\hline \multicolumn{2}{|l|}{ Test } & Value & \multicolumn{3}{|c|}{ Degrees of freedom } & \multicolumn{2}{|c|}{$\begin{array}{l}\text { Significance } \\
\text { level }\end{array}$} & \multicolumn{2}{|c|}{$\begin{array}{l}\text { Cramer } \\
\text { coefficient }\end{array}$} \\
\hline \multicolumn{2}{|l|}{ Chi square } & 8.14 & 4 & & \multicolumn{2}{|c|}{0.136} & 0.121 & \\
\hline
\end{tabular}

The results indicate that there is not significant relationship between education and the effectiveness of media educations of Iran Helal institute in increasing public awareness for rehabilitation after possible earthquake in Tehran. Therefore, $\mathrm{H} 0$ is accepted and $\mathrm{H} 1$ is rejected.

\section{THE FIFTH HYPOTHESIS ANALYSIS}


H0: There is not significant relationship between employment status and the effectiveness of media educations of Iran Helal institute in increasing public awareness for rehabilitation after possible earthquake in Tehran

H1: There is significant relationship between employment status and the effectiveness of media educations of Iran Helal institute in increasing public awareness for rehabilitation after possible earthquake in Tehran

Table 5 Investigating relationship between employment status and the effectiveness of media educations of Iran Helal institute in increasing public awareness for rehabilitation after possible earthquake in Tehran

\begin{tabular}{|c|c|c|c|c|c|c|c|c|c|}
\hline \multicolumn{2}{|c|}{$\begin{array}{l}\text { Employment } \\
\text { Awareness }\end{array}$} & & Jobless & Housewife & Employee & \multicolumn{2}{|c|}{$\begin{array}{l}\text { Self- } \\
\text { employed }\end{array}$} & Student & Total \\
\hline \multirow[t]{2}{*}{$\begin{array}{l}\text { Previous } \\
\text { score }\end{array}$} & $\begin{array}{l}\text { Lower } \\
\text { than } \\
\text { average }\end{array}$ & $\begin{array}{l}\text { Number } \\
\text { Percent }\end{array}$ & $\begin{array}{l}223 \\
79.64\end{array}$ & $\begin{array}{l}413 \\
79.42\end{array}$ & $\begin{array}{l}259 \\
80.68\end{array}$ & \multicolumn{2}{|c|}{$\begin{array}{l}413 \\
82.76\end{array}$} & $\begin{array}{l}212 \\
75.71\end{array}$ & $\begin{array}{l}1520 \\
80\end{array}$ \\
\hline & $\begin{array}{l}\text { Above } \\
\text { average }\end{array}$ & $\begin{array}{l}\text { Number } \\
\text { Percent }\end{array}$ & $\begin{array}{l}57 \\
20.35\end{array}$ & $\begin{array}{l}107 \\
20.57\end{array}$ & $\begin{array}{l}62 \\
19.31\end{array}$ & \multicolumn{2}{|c|}{$\begin{array}{l}86 \\
17.23\end{array}$} & $\begin{array}{l}68 \\
24.28\end{array}$ & $\begin{array}{l}380 \\
20\end{array}$ \\
\hline \multirow[t]{2}{*}{ Next Score } & $\begin{array}{l}\text { Lower } \\
\text { than } \\
\text { average }\end{array}$ & $\begin{array}{l}\text { Number } \\
\text { Percent }\end{array}$ & $\begin{array}{l}185 \\
66.07\end{array}$ & $\begin{array}{l}365 \\
70.19\end{array}$ & $\begin{array}{l}213 \\
66.35\end{array}$ & \multicolumn{2}{|c|}{$\begin{array}{l}325 \\
65.13\end{array}$} & $\begin{array}{l}159 \\
56.78\end{array}$ & $\begin{array}{l}1247 \\
65.63\end{array}$ \\
\hline & $\begin{array}{l}\text { Above } \\
\text { average }\end{array}$ & $\begin{array}{l}\text { Number } \\
\text { Percent }\end{array}$ & $\begin{array}{l}95 \\
33.92 \\
\end{array}$ & $\begin{array}{l}155 \\
29.80\end{array}$ & $\begin{array}{l}108 \\
33.64\end{array}$ & \multicolumn{2}{|c|}{$\begin{array}{l}174 \\
34.86\end{array}$} & $\begin{array}{l}121 \\
43.21\end{array}$ & $\begin{array}{l}653 \\
34.36 \\
\end{array}$ \\
\hline \multicolumn{2}{|l|}{ Total } & \multicolumn{2}{|l|}{280} & 520 & 321 & \multicolumn{2}{|c|}{499} & 280 & 1900 \\
\hline Test & \multicolumn{3}{|c|}{ Value } & $\begin{array}{l}\text { Degrees of } \\
\text { freedom }\end{array}$ & \multicolumn{2}{|c|}{$\begin{array}{l}\text { Significance } \\
\text { level }\end{array}$} & \multicolumn{3}{|c|}{ Cramer coefficient } \\
\hline Chi square & \multicolumn{3}{|c|}{9.18} & 4 & \multicolumn{2}{|c|}{0.165} & \multicolumn{3}{|c|}{0.113} \\
\hline
\end{tabular}

The results indicate that there is not significant relationship between employment status and the effectiveness of media educations of Iran Helal institute in increasing public awareness for rehabilitation after possible earthquake in Tehran. Therefore, $\mathrm{H} 0$ is accepted and $\mathrm{H} 1$ is rejected.

\section{CONCLUSION}

Overall, this study shows that media educations of Helal institute on people's awareness about prevention and preparing and informing the public about the rehabilitation after the earthquake is effective. However, in some age and education groups as well as rehabilitation training needs serious revision. Certainly, there is still the subject of much study to accept the fact that public education in developed countries and in developing countries is necessary. Since the government alone can carry out the necessary measures to confront and deal with the harmful consequences of natural disasters like earthquakes, public education is as one of the most crucial components of the preparation. (10)

Overall results showed that:

1: There is not significant relationship between age and the effectiveness of media educations of Iran Helal institute in increasing public awareness for rehabilitation after possible earthquake in Tehran

2: There is not significant relationship between gender and the effectiveness of media educations of Iran Helal institute in increasing public awareness for rehabilitation after possible earthquake in Tehran 3: There is not significant relationship between the location and the effectiveness of media educations of Iran Helal institute in increasing public awareness for rehabilitation after possible earthquake in Tehran 4: There is not significant relationship between education and the effectiveness of media educations of Iran Helal institute in increasing public awareness for rehabilitation after possible earthquake in Tehran 
5: There is not significant relationship between employment status and the effectiveness of media educations of Iran Helal institute in increasing public awareness for rehabilitation after possible earthquake in Tehran

\section{REFERENCES}

1. Rafipour, F. (1999). Mass media and changing social values. Tehran. Learn book publishing.

2. Kianmehr, N. (2003). Prepare families to deal with unexpected events. Proceedings of the First International Congress on Health and crisis management in disasters Page 360

3.Community Based Disaster Risk Management (2007) Organized byAsian Disaster Preparedness Center, Bangkok, Thailand. A Literature review and reappraisal

4. Vindal, Sun et al. (1997). The application of communication theories. (Translated by Alireza Dehghan). Tehran . Center for Media Studies \& Research

5.Everet Rogers (2003).Information Needs Analysis .What we want to find out and what the literature tells us?2nd ed. RA399A1L54

6. Malek Mohammadi, M. (2006). Public education, self-aid training, the role of mass media, training courses maneuver and Red Crescent in this city. Proceedings of the Third International Congress on Health and crisis management in disasters, Page 57

7. Mehdi Pour, A (2003). Pyramid of self-aid measures in the country with public education and public participation. Proceedings of the First International Congress on Health and crisis management in disasters, Page 43

8. Ghanjal, A. (2003). Its role and self-aid in disasters. Proceedings of the First International Congress on Health and crisis management in disasters, Page 176

9.Lorna, Victoria (2003), COMMUNITY BASED DISASTER MANAGEMENT IN THE PHILIPPINES: MAKING A DIFERENCE IN PEOPLE'S LIVES. $9 \mathrm{p}$

10. Lak, M. (2004). Workshop on Health in infectious disease control in disasters. Proceedings of the Second International Congress of Health and crisis management in disasters, Page 73 